\title{
Essential oil constituents of Desmos cochinchinensis Lour, and Polyalthia longifolia var. Pendula Hort from Vietnam
}

\author{
Tran Dinh Thang ${ }^{1, *}$, Do Ngoc Dai ${ }^{2}$, Tran Minh Hoi ${ }^{2}$, Isiaka A. Ogunwande ${ }^{3, *}$ \\ ${ }^{1}$ Faculty of Chemistry, Vinh University, 182-Le Duan, Vinh City, Nghe An Province, Vietnam \\ ${ }^{2}$ Faculty of Biology, Vinh University, 182-Le Duan, Vinh City, Nghe An Province, Vietnam \\ ${ }^{3}$ Natural Products Research Unit, Department of Chemistry, Faculty of Science, Lagos State University, Badagry Expressway, Ojo, Lasu \\ Post office, Ojo, Lagos, Nigeria
}

\section{Email address:}

thangtd@vinhuni.edu.vn (T. D. Thang), daidn23@gmail.com (D. N. Dai), isiaka.ogunwande@lasu.edu.ng (I. A. Ogunwande), tran.minhhoi@yahoo.com (T.M. Hoi)

\section{To cite this article:}

Tran Dinh Thang, Do Ngoc Dai, Tran Minh Hoi, Isiaka A. Ogunwande. Essential Oil Constituents of Desmos Cochinchinensis Lour, and Polyalthia Longifolia var. Pendula Hort from Vietnam. Plant. Vol. 1, No. 4, 2013, pp. 45-49. doi: 10.11648/j.plant.20130104.11

\begin{abstract}
The essential oils obtained by hydrodistillation from two Annonaceace plants from Vietnam were analysed by gas chromatography (GC) coupled with mass spectrometry (GC/MS). The main conpounds identified in bark oil of Polyalthia longifolia var. pendula Hort were zingiberene (26.7\%), $\beta$-caryophyllene $(11.1 \%)$ and $\beta$-bisabolene $(7.9 \%)$. The major compounds in the flower oil of Desmos cochinchinensis Lour., were the monoterpenoids camphor (59.1\%), limonene (8.9\%), $\alpha$-pinene $(8.6 \%)$ and camphene $(6.0 \%)$.
\end{abstract}

Keywords: Annonceae, Desmos Cochinchinensis, Polyalthia Longifolia var. Pendula, Essential Oils, GC/MS, Terpenoids

\section{Introduction}

In continuation of our studies on the volatile oil composition of Vietnamese flora [1], we report herein the essential oil constituents of two species in the Annonanaceae family. Desmos Lour., is a small genus in the family Annonaceae. About 25-30 species are endemic to tropical and subtropical Asia. Desmos cochinchinensis Lour., or Dwarf Ylang Ylang shrub, is a spreading shrub that likes shady places and may develop into a higher climber. The flowers open between April and July. Young flowers are green and inconspicuous. Only mature yellow flowers have strong lemon-like fruity scent that can be detected at a distance, especially during the evenings. $D$. cochinchinensis as a folk medicine is used for treatment of malaria in China [2]. Studies have shown that the plant is a source of biologically active compounds [3]. There are relatively fewer studies on the analyses of the content and composition of flower essential oil from Desmos species. Trans-caryophyllene $(56.2 \%)$ and spathulenol $(61.5 \%)$ respectively were the main compounds identified in the young and ripened flowers of D. cochinchinensis [4]. $\beta$-Caryophyllene (28.9\%), bicyclogermacrene (11.5\%), $\alpha$-humulene $(7.2 \%)$, germacrene D (7.2\%) and $\beta$-elemene
(6.4\%) occurred in higher amounts in Desmos chinensis [5]. Most studies have focused on the leaf oil constituents of Desmos species [6-8].

A handsome ornamental of the family is the weeping form of the mast tree, Polyalthia longifolia var. pendula Hourt. Its shining, brilliant green, willowy, wavy-edged leaves hang from pendant branches that almost clasp the tall, straight trunk. The leaves are used as temple decorations in India. It is a lofty evergreen tree, commonly planted due to its effectiveness in alleviating noise pollution. It exhibits symmetrical pyramidal growth with willowy weeping pendulous branches and long narrow lanceolate leaves with undulate margins. The tree is known to grow over $30 \mathrm{ft}$ in height. Extracts and compounds isolated from the plants have been reported to possess a number of biological activities $[9,10]$. There is only one literature information on its volatile oil components [11].

\section{Materials and Methods}

\subsection{Plants Collection}

The stem barks of $P$. longifolia var. pendula were obtained from Thanh Hóa Province, Vietnam, in September 2011. 
However, the flower of $D$. cochinchinensis were harvested from Vũ Quang, National park, Hà Tĩnh Province, Vietnam, in September 2011. Voucher specimens DND 63 and, DND 195 respectively for D. cochinchinensis and P. longifolia var. pendula have been deposited at the Botany Museum Vinh University, Vietnam, for future references.

\subsection{Extraction of the Oils}

About $0.5 \mathrm{~kg}$ of air-dried sample of each plant was shredded and their oils were obtained by hydrodistillation for $3 \mathrm{~h}$ at normal pressure, according to the Vietnamese Pharmacopoeia [12]. The plant samples yielded a low content of essential oils: $0.15 \%(\mathrm{v} / \mathrm{w} ; D$. cochinchinensis); and $0.10 \%$ (v/w; P. longifolia var. pendula stem bark), calculated on a dry weight basis. Both oils were h light yellow in colouration.

\subsection{Analysis of the Oils}

About $15 \mathrm{mg}$ of each oil sample, which was dried with anhydrous sodium sulfate, was dissolved in $1 \mathrm{~mL}$ of hexane (for spectroscopy or chromatography). Gas chromatography (GC) analysis was performed on Agilent Technologies HP 6890 Plus Gas chromatograph equipped with a FID and fitted with HP-Wax and HP-5MS columns (both $30 \mathrm{~m} \times 0.25$ $\mathrm{mm}$, film thickness $0.25 \mu \mathrm{m}$, Agilent Technology). The analytical conditions were: carrier gas $\mathrm{H}_{2}(3 \mathrm{~mL} / \mathrm{min})$, injector temperature (PTV) $250{ }^{\circ} \mathrm{C}$, detector temperature 260 ${ }^{\circ} \mathrm{C}$, column temperature programmed $60{ }^{\circ} \mathrm{C}$ ( 2 min hold $)$ to $220{ }^{\circ} \mathrm{C}$ (10 min hold $)$ at $4{ }^{\circ} \mathrm{C} / \mathrm{min}$. Samples were injected by splitting and the split ratio was $10: 1$. The volume injected was $1.0 \mu \mathrm{L}$. Inlet pressure was $6.1 \mathrm{kPa}$.

An Agilent Technologies HP 6890N Plus Chromatograph fitted with a fused silica capillary column HP-5 MS column ( $30 \mathrm{~m} \times 0.25 \mathrm{~mm}$, film thickness $0.25 \mu \mathrm{m}$ ) and interface with a mass spectrometer HP 5973 MSD was used for the GC/MS analysis, under the same condition for GC analysis. The conditions were the same as described above with $\mathrm{He}(3$ $\mathrm{mL} / \mathrm{min}$ ) as carrier gas. The MS conditions were as follows: ionization voltage $70 \mathrm{eV}$; emission current $40 \mathrm{~mA}$; acquisitions scan mass range of 35-350 amu at a sampling rate of $1.0 \mathrm{scan} / \mathrm{s}$. The MS fragmentation patterns was checked with those of other essential oils of known composition patterns with Wiley (Wiley 9th Version), NIST 08 Libraries (on ChemStation HP), with those in the literature and also with standard substances.

\subsubsection{Identification of the Constituents}

The identification of constituents was performed on the basis of retention indices (RI) determined with reference to the homologous series of n-alkanes, under identical experimental conditions, co-injection with standards (Sigma-Aldrich, St. Louis, MO, USA) or known essential oil constituents, MS library search (NIST 08 and Wiley 9th Version), and by comparing with MS literature data [13-15]. The relative amounts of individual components were calculated based on the GC peak area (FID response) without using correction factors.

\section{Results and Discussion}

The chemical composition of the oils is summarized in Table 1. Monoterpenes (95.1\%) were the dominant class of compound identified in D. cochinchinensis. Camphor (59.1\%) was the most singly abundant compound of these monoterpenoids. Other significant ones included limonene $(8.9 \%), \alpha$-pinene $(8.6 \%)$ and camphene $(6.0 \%)$. Sesquiterpenes compound have been identified in flower oil from a previous studies on this species [4] and D. chinensis [5]. Among these, $\beta$-caryophyllene, bicyclogermacrene, $\alpha$-humulene and germacrene $\mathrm{D}$ are common compounds identified in the two reports.

Sesquiterpenes, represented by zingiberene (26.7\%), $\beta$-caryophyllene $(11.1 \%)$ and $\beta$-bisabolene $(7.9 \%)$ were the dominant class of compound of $P$. longifolia var. pendula. In a previous study [11], high quantities of $\delta$-cadinene $(24.5 \%)$, zingiberene (19.6\%) and aromadendrene (119.1\%) were identified in the oil. However, $\delta$-cadinene was conspicuously absent in our result while caryophyllene was identified in low quantity in previous study [11].

From Table 2, four chemical forms of the oils of Polyalthia species may be proposed. These are oils with abundant of sesquiterpene hydrocarbons as could be seen in $P$. longifolia var. pendula [11], P. longifolia [16], P. suaveolens [17] and P. nitidissima [18]; oils relative amounts of hydrocarbon and oxygenated sesquiterpenes as exemplified by $P$. australis and Polyalthia sp. (Wyvuri B.P.) [18]; oils dominated by oxygenated sesquiterpenes as seen in P. michaelii [18]; oils consisting of monoterpene hydrocarbons which are found in the fruit of P. suaveolens [17] and P. nitidissima [18].

Table 1. Percentage of compounds identified in the oil samples.

\begin{tabular}{|c|c|c|c|c|}
\hline Compounds & $\mathbf{R I}^{\mathrm{a}}$ & LRI $^{b}$ & D.c & P.l \\
\hline Tricyclene & 926 & 921 & 0.1 & 0.2 \\
\hline$\alpha$-Thujene & 931 & 924 & 0.6 & - \\
\hline$\alpha$-Pinene & 939 & 932 & 8.6 & 5.7 \\
\hline Camphene & 953 & 946 & 6.0 & 1.8 \\
\hline Sabinene & 976 & 959 & 0.8 & 0.1 \\
\hline$\beta$-Pinene & 980 & 974 & - & 0.1 \\
\hline$\beta$-Pinene & 990 & 988 & 3.8 & 1.7 \\
\hline$\alpha$-Phellandrene & 1006 & 1002 & 1.3 & $\operatorname{Tr}$ \\
\hline ס-3-Carene & 1011 & 1008 & 0.1 & - \\
\hline$\alpha$-Terpinene & 1017 & 1014 & 0.2 & $\operatorname{Tr}$ \\
\hline
\end{tabular}




\begin{tabular}{|c|c|c|c|c|}
\hline Compounds & $\mathrm{RI}^{\mathrm{a}}$ & LRI $^{b}$ & D.c & $P . l$ \\
\hline$\rho$-Cymene & 1026 & 1020 & 0.5 & $\mathrm{Tr}$ \\
\hline Limonene & 1032 & 1024 & 8.9 & 0.4 \\
\hline 1,8-Cineole & 1034 & 1026 & 1.5 & - \\
\hline $\begin{array}{l}(Z)-\beta- \\
\text { Ocimene }\end{array}$ & 1043 & 1032 & - & 0.1 \\
\hline $\begin{array}{l}(E)-\beta- \\
\text { Ocimene }\end{array}$ & 1052 & 1044 & 0.1 & 2.2 \\
\hline$\gamma$-Terpinene & 1061 & 1054 & 0.4 & 0.1 \\
\hline cis-Sabinene hydrate & 1070 & 1065 & 0.1 & - \\
\hline$\alpha$-Terpinolene & 1089 & 1086 & 1.0 & 0.1 \\
\hline 2-Nonanone & 1090 & 1087 & - & $\operatorname{Tr}$ \\
\hline Linalool & 1100 & 1095 & 0.1 & $\operatorname{Tr}$ \\
\hline allo-Ocimene & 1128 & 1128 & - & 0.1 \\
\hline Camphor & 1146 & 1141 & 59.1 & - \\
\hline 1-Nonene ${ }^{d}$ & 1149 & - & - & 0.2 \\
\hline Borneol & 1169 & 1165 & 0.4 & - \\
\hline Terpinen-4-ol & 1177 & 1175 & 0.5 & - \\
\hline$\alpha$-Terpineol & 1189 & 1186 & 0.6 & - \\
\hline Bornyl acetate & 1289 & 1287 & 0.4 & 1.6 \\
\hline Bicycloelemene & 1327 & $1338^{\mathrm{c}}$ & - & $\operatorname{Tr}$ \\
\hline Neryl acetate & 1362 & 1359 & - & 0.1 \\
\hline$\alpha$-Ylangene & 1375 & 1373 & - & 0.1 \\
\hline$\alpha$-Copaene & 1377 & 1374 & - & 0.1 \\
\hline$\beta$-Elemene & 1391 & 1389 & 0.1 & 0.1 \\
\hline Longifolene & 1408 & 1407 & - & $\operatorname{Tr}$ \\
\hline$\alpha$-Cedrene & 1412 & 1410 & - & 0.2 \\
\hline$\beta$-Caryophyllene & 1419 & 1417 & 0.2 & 11.1 \\
\hline$\gamma$-Elemene & 1435 & 1432 & - & 1.7 \\
\hline trans- $\alpha$-Bergamotene & 1437 & 1434 & $\operatorname{Tr}$ & - \\
\hline$\alpha$-Guaiene & 1440 & 1437 & - & 0.1 \\
\hline Aromadendrene & 1441 & 1439 & - & 5.7 \\
\hline$\alpha$-Humulene & 1454 & 1452 & - & 4.4 \\
\hline (E)- $\beta$-Farnesene & 1457 & 1454 & - & 3.0 \\
\hline ar-curcumene & 1481 & 1479 & - & 1.9 \\
\hline$\gamma$-Curcumene & 1483 & 1481 & - & 1.4 \\
\hline Germacrene D & 1486 & 1484 & 0.2 & - \\
\hline$\beta$-Selinene & 1490 & 1489 & 0.4 & 0.8 \\
\hline Zingiberene & 1494 & 1493 & - & 26.7 \\
\hline Cadina-1,4-diene & 1496 & 1495 & - & 0.1 \\
\hline$\alpha$-Selinene & 1498 & 1498 & - & 2.2 \\
\hline$\beta$-Bisabolene & 1505 & 1505 & - & 7.9 \\
\hline$(E, E)$ - $\alpha$-Farnesene & 1506 & 1505 & - & 0.3 \\
\hline cis- $\alpha$-Bisabolene & 1507 & 1506 & - & 0.7 \\
\hline$\gamma$-Cadinene & 1514 & 1513 & - & 0.2 \\
\hline trans- $\gamma$-Bisabolene & 1515 & 1514 & - & 0.3 \\
\hline $\begin{array}{l}\text { cis- }(Z)-\alpha \text {-Bisabolene } \\
\text { epoxide }^{d}\end{array}$ & 1515 & - & - & 0.6 \\
\hline$\beta$-Sesquiphellandrene & 1523 & 1521 & - & 1.6 \\
\hline$\delta$-Cadinene & 1525 & 1522 & $\operatorname{Tr}$ & - \\
\hline$\alpha$-Calacorene & 1546 & 1544 & - & 0.1 \\
\hline Germacrene B & 1561 & 1559 & 0.1 & - \\
\hline (E)-Nerolidol & 1563 & 1561 & - & 0.1 \\
\hline Palustrol & 1566 & 1567 & - & 0.6 \\
\hline $\begin{array}{l}\alpha \text {-Caryophyllenyl al- } \\
\text { cohol }\end{array}$ & 1572 & 1570 & - & 1.1 \\
\hline Spathulenol & 1576 & 1577 & - & 0.1 \\
\hline Caryophyllene oxide & 1583 & 1582 & - & 1.3 \\
\hline Globulol & 1585 & 1590 & - & 0.9 \\
\hline Viridiflorol & 1593 & 1592 & - & 0.4 \\
\hline allo-Aromadendrene & 1641 & 1639 & - & 0.5 \\
\hline
\end{tabular}




\begin{tabular}{|c|c|c|c|c|}
\hline Compounds & $\mathbf{R I}^{\mathrm{a}}$ & LRI $^{b}$ & D.c & P.l \\
\hline$\alpha$-Muurolol & 1644 & 1644 & - & 0.4 \\
\hline$\tau$-Cadinol ${ }^{\mathrm{d}}$ & 1659 & - & - & 0.8 \\
\hline$\alpha$-Bisabolol & 1686 & 1685 & - & 0.8 \\
\hline$(Z, Z)$-Farnesol & 1718 & 1724 & - & 1.3 \\
\hline Benzyl benzoate & 1760 & 1759 & $\operatorname{Tr}$ & - \\
\hline Eicosane & 2000 & 2000 & - & $\operatorname{Tr}$ \\
\hline Abietatriene & 2057 & 2055 & - & $\operatorname{Tr}$ \\
\hline Total & & & 96.1 & 94.1 \\
\hline $\begin{array}{l}\text { Monoterpene hydro- } \\
\text { carbons }\end{array}$ & & & 62.7 & 12.6 \\
\hline $\begin{array}{l}\text { Oxygenated monoter- } \\
\text { penes }\end{array}$ & & & 32.4 & 1.2 \\
\hline $\begin{array}{l}\text { Sesquiterpene hydro- } \\
\text { carbons }\end{array}$ & & & 1.0 & 72.0 \\
\hline $\begin{array}{l}\text { Oxygenated sesquiter- } \\
\text { penes }\end{array}$ & & & - & 8.3 \\
\hline Diterpenes & & & - & $\operatorname{Tr}$ \\
\hline Others & & & $\operatorname{Tr}$ & 0.2 \\
\hline
\end{tabular}

${ }^{a}$ Retention indices on HP-5MS column; ${ }^{\text {b }}$ Literature retention indices (Adams, 2007, see Experimental); ${ }^{\mathrm{c}}$ Retention indices from Joulain and Koenig (see Experimental); ${ }^{\mathrm{d}}$ Identification by MS pattern, column retention indices and use of authentic home- made spectral; $\operatorname{Tr}$, trace amount $<0.1 \%$; - not identified and not found in Literature reference; D.c = Desmos cochinchinensis; P.1 = Polyalthia longifolia var. pendula

Table 2. Chemical forms of essential oils of P. longifolia species

\begin{tabular}{|c|c|c|c|c|}
\hline Chemical forms & Species & Major components & Origin & Ref \\
\hline \multirow{6}{*}{$\begin{array}{l}\text { Oils with abundance } \\
\text { of sesquiterpene } \\
\text { hydrocarbons }\end{array}$} & $\begin{array}{l}\text { P. longifolia var. } \\
\text { Pendula }\end{array}$ & $\begin{array}{l}\beta \text {-caryophyllene }(30.0 \%) \text {, zingiberene }(21.7 \%) \text {, } \\
\text { aromadendrene }(15.2 \%) \text { and } \beta \text {-selinene }(9.1 \%)\end{array}$ & Vietnam & This study \\
\hline & $"$ & $\begin{array}{l}\delta \text {-cadinene }(24.5 \%) \text {, zingiberene }(19.6 \%) \text { and } \\
\text { aromadendrene }(19.1 \%)\end{array}$ & “ & 11 \\
\hline & P. longifolia & $\begin{array}{l}\text { allo-aromadendrene (19.7\%), caryophyllene oxide (14.4\%), } \\
\text { and } \beta \text {-caryophyllene }(13.0 \%)\end{array}$ & Nigeria & 16 \\
\hline & P. longifolia ${ }^{\text {a }}$ & $\begin{array}{l}\alpha \text {-copaene/ } \alpha \text {-muurolol (ca. } 8.7 \%), \beta \text {-selinene }(8.6 \%) \\
\text { viridiflorene }(8.1 \%), \alpha \text {-guaiene }(7.8 \%) \\
\text { and allo-aromadendrene } / \delta \text {-cadinene (ca.7.4\%) }\end{array}$ & “ & “ \\
\hline & P. suaveolens & $\beta$-caryophyllene and humulene (both $34 \%$ ) & Gabon & 17 \\
\hline & P. nitidissima $a^{\#}$ & $\begin{array}{l}\beta \text {-caryophyllene, aromadendrene, germacrene } \mathrm{D} \text {, } \\
\text { bicyclogermacrene, } \delta \text {-cadinene, and spathulenol }\end{array}$ & Australia & 18 \\
\hline \multirow{2}{*}{$\begin{array}{l}\text { Oils with } \\
\text { relative amounts } \\
\text { of hydrocarbon } \\
\text { and oxygenated } \\
\text { sesquiterpenes }\end{array}$} & P. australis $\#$ & $\begin{array}{l}\beta \text {-caryophyllene, germacrene } \mathrm{D} \text {, bicycligermacrene, } \\
\text { caryophyllene oxide and spathulenol }\end{array}$ & “ & “ \\
\hline & $\begin{array}{l}\text { Polalthia sp. } \\
\text { (Wyvuri B.P.) }^{\#}\end{array}$ & $\begin{array}{l}\gamma \text {-elemene, germacrene } \mathrm{D} \text {, bicycolgermacrene, } \\
\text { germacrene } \mathrm{B} \text {, ledol, globulol and spathulenol. }\end{array}$ & “ & “ \\
\hline $\begin{array}{l}\text { Oils dominated } \\
\text { by oxygenated } \\
\text { sesquiterpenes }\end{array}$ & P. michaelii ${ }^{\#}$ & spathulenol & “ & “ \\
\hline \multirow{2}{*}{$\begin{array}{l}\text { Oils consisting of } \\
\text { monoterpene } \\
\text { hydrocarbons }\end{array}$} & P. nitidissima ${ }^{\#}$ & $\alpha$-pinene, limonene and (E)- $\beta$-ocimene & “ & “ \\
\hline & P. suaveolens $\#, \mathrm{~b}$ & myrcene, $\beta$-pinene and limonene & Gabon & 17 \\
\hline
\end{tabular}

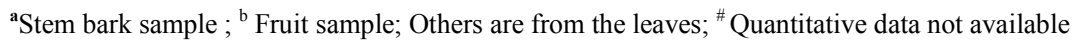

\section{Acknowledgements}

The authors are grateful to NAFOSTED (Vietnam) for the financial support of this study through the Project $\mathrm{Nr}$. 104.01-2010.27.

\section{References}

[1] Dai DN, Tran MH, Thang TD and Ogunwande IA. (2012) Chemical compositions of the leaf essential oils of some Annonaceae from Vietnam. Natural Product Communica- 
tions, 7, 2, 231-234.

[2] Nguyen TB. (2000) Flora of Vietnam. Science and Technology Publishing House, Hanoi, Vietnam, Vol. 1.

[3] Bajgai SP, Prachyawarakorn V, Mahidol C, Ruchirawat S and Kittakoop P. (2011) Hybrid flavan- chalcones, aromatase and lipoxygenase inhibitors, from Desmos cochinchinensis. Phytochemistry, 72, 2062-2067.

[4] Rang DD, Tuong DT and Linh DK. (2004) Preliminary study on the chemical constituent of Desmos cochinchinensis Lour. in Nghe An province. Journal of Applied Chemistry, 10, 23-26.

[5] Tran HT, Tran MH, Ninh KB, Nguyen QH, Vu TM, Bighelli A, Castola V and Casanova J. (2003) Chemical composition of the flower essential oil of Desmos chinensis Lour. from Vietnam. Journal of Pharmaceutical, Vinh University, 1, 23-24.

[6] Song X-H, Xiong Y, Zhou K-D, YiX, Zen W-M, Peng L. et al. (2006) The component of volatile oils from the fresh flowers of Desmos chinensis. Natural Product Research Development Retrieved from http://www.natureproduct.cn

[7] Dai DN, Thang TD and Nguyen XD. (2009) Chemical composition of the leaf essential oil of Desmos cochinchinensis var. fulvescens Ban from Hatinh. Journal of Biology, $31,61-64$

[8] Brophy JJ, Goldsack RJ and Forster PI. (2002) The leaf oils of the Australian species of Desmos (Annonaceae). Journal of Essential Oil Research, 14, 298-301.

[9] Sashidhara KV, Singh SP, Kant R, Maulik PR, Sarkar J, Kanojiya S and Kumar KR. (2010) Cytotoxic cycloartane triterpene and rare isomeric bisclerodane diterpenes from the leaves of Polyalthia longifolia var. pendula. Bioorganic Medicinal Chemistry Letter, 20, 5767-5771.
[10] Chung-Yi C, Fang-Rong C, Yao-Ching S, Tian-Jye H, Yi-Chen C, Huang-Yi T, Hua-Chien C, Shu-Jen C, Ming-Chu $\mathrm{H}$ and Yang-Chang W. (2000) Cytotoxic Constituents of Polyalthia longifolia var. pendula . Journal of Natural Product, $63,1475-1478$.

[11] Nguyen TC, Thuy LT, Nguyen HD, Thang TD and Dai DN. (2009) Chemical composition of the leaf essential oil of Polyalthia longifolia var. pendula Hort. from Nghean, Proceedings of the 3rd National Scientific conference on Ecology and Biological resources Agricultural Publishing House, Hanoi, Vietnam, pp. 930-932.

[12] Vietnamese Pharmacopoeia, (1997) Medical Publishing House, Hanoi, Vietnam.

[13] Joulain D and Koenig WA. (1989) The Atlas of Spectral Data of Sesquiterpene Hydrocarbons. E. B. Verlag, Hamburg, Germany.

[14] Heller SR and Milne GWA. (1978,1980,1983) EPA/NIH Mass Spectral Data Base, U.S. Government Printing Office, Washington D.C.

[15] Adams RP. (2007) Identification of Essential Oil Components by Gas Chromatography/Mass Spectrometry. Allured, Carol Stream, IL, USA

[16] Ogunbinu AO, Ogunwande IA, Essien ., Cioni PL and Flamini G. (2007) Sesquiterpenes- rich essential oils of Polyalthia longifolia Thw. (Annonaceae) from Nigeria. Journal of Essential Oil Research, 19, 419-421.

[17] Cravo L, Perineau F, Delmas M and Bessiere J.-M. (1991) Chemical composition of the leaf and fruit oil of Polyalthia suaveolens Eng. Et Diels. Journal of Essential Oil Research, $3,459-461$.

[18] Brophy JJ, Goldsack RJ and Forster PI. (2001) Leaf oils of the Australian species of Polyalthia (Annonaceae). Journal of Essential Oil Research, 12, 5-7.. 